\title{
Faktor-Faktor yang Mempengaruhi Financial Performance Perusahaan Industri Dasar dan Kimia di Indonesia
}

\author{
Michelle Angela, Maswar Abdi \\ Program Studi Manajemen Fakultas Ekonomi \& Bisnis \\ Universitas Tarumanagara \\ Email: Michelleliawandi9@gmail.com
}

\begin{abstract}
This study aims to examine the effects of operational efficiency, assets effectiveness, and financial leverage on financial performance in basic industry and chemical companies listed in IDX 2014-2018. The research is conducted by taking 53 samples using purposive sampling method and the method used is multiple panel data regression analysis using $e$ views 9.0 software. The results show that the operational efficiency, assets effectiveness, and financial leverage are significantly affect financial performance of Basic Industry and Chemical Companies listed in IDX.
\end{abstract}

Keywords: Operational Efficiency, Assets Effectiveness, Financial Leverage, Financial Performance.

Abstrak: Penelitian ini dilakukan dengan tujuan untuk mengetahui pengaruh efisiensi operasional, efektivitas aset, dan financial leverage terhadap financial performance pada perusahaan industri dasar dan kimia yang terdaftar di BEI periode 2014-2018. Penelitian ini menggunakan 53 perusahaan sebagai sample yang dipilih dengan metode purposive sampling dan menggunakan metode analisis regresi berganda data panel dengan menggunakan perangkat lunak e-views 9.0. Hasil penelitian menunjukkan bahwa efisiensi operasional, efektivitas aset dan financial leverage berpengaruh signifikan terhadap financial performance perusahaan industri dasar dan kimia yang terdaftar di BEI.

Kata kunci: Efisiensi Operasional, Efektivitas Aset, Financial Leverage, Financial Performance.

\section{LATAR BELAKANG}

Laporan keuangan merupakan salah satu alat yang dapat digunakan oleh manajer untuk berkomunikasi dengan investor ataupun calon investor perusahaan. Untuk dapat memikat para investor, perusahaan harus memiliki laporan keuangan yang baik. Laporan keuangan digunakan untuk menganalisa kinerja keuangan atau financial performance suatu perusahaan. Financial performance merupakan alat untuk mengukur seberapa jauh perusahaan sudah mencapai tujuannya, yakni menyejahterakan atau memaksimumkan nilai pemegang atau pemilik perusahaan. Tolak ukur financial performance melalui nilai buku perusahaan, dimana nilai buku dipengaruhi dan dikontrol dari dalam perusahaan itu sendiri. Di dalam pengukuran financial performance, perusahaan menggunakan rasio profitabilitas dimana rasio ini dapat menunjukkan kemampuan suatu perusahaan dalam menghasilkan keuntungan (laba). Berbagai faktor yang dapat mempengaruhi financial performance ukuran perusahaan, aktivitas rasio, working capital, efisiensi perusahaan, likuiditas perusahaan, dan leverage perusahaan. Untuk mendapatkan keuntungan kompetitif, maka setiap faktor-faktor tersebut harus dipertimbangkan dalam menyusun strategi perusahaan. Dengan menggunakan analisis model profitabilitas Du Pont, maka manajer dapat mengidentifikasi bagaimana cara yang terbaik untuk terus meningkatkan kinerja keuangan perusahaan. Faktor yang digunakan 
dalam model Du Pont adalah efisiensi operasional yang diukur dengan cost to revenue ratio (Batchimeg, 2017), efektivitas aset yang diukur dengan total assets turnover (Warrad \& Nassar, 2017), dan financial leverage yang diukur dengan debt to equity ratio (Atidhira \& Yustina, 2015) dimana faktor-faktor tersebut paling sering mengalami perbedaan hasil penelitian antara penelitian yang satu dengan yang lain.

Perkembangan industri dasar dan kimia tidak lepas dari investasi karena sektor ini tergolong padat modal dan membutuhkan teknologi yang tinggi. Industri ini merupakan tulang punggung perekonomian Indonesia karena mendukung kegiatan manufaktur utama seperti industri makanan \& minuman, otomotif, tekstil, farmasi, dan eletronik. Penanaman modal ini memacu peningkatan kinerja positif industri dasar dan kimia untuk terus dapat meningkatkan nilai perusahaan. Salah satu untuk mewujudkan nilai tersebut dengan adanya peningkatan financial performance yang dapat memberikan efek kepercayaan kepada investor untuk terus memacu investasi atau menanamkan modalnya ke dalam perusahaan.

\section{KAJIAN TEORI}

Du Pont system of analysis. Gitman (2015, p. 136) menjelaskan bahwa sistem ini dapat digunakan untuk membedah sebuah laporan keuangan untuk melihat kondisi keuangan suatu perusahaan. Sistem ini menggabungkan income statement (laporan rugi-laba) dengan statement of financial position (laporan neraca) untuk mengukur tingkat pengembalian (return) yang didapat atau peningkatan kekayaan pemilik perusahaan. ROE mencerminkan tingkat pengembalian dari pemegang saham (ekuitas) yang merupakan minat atau tujuan investor di dalam bisnis.

Pecking Order Theory. Brigham \& Houston (2015) mengungkapkan bahwa terdapat urutan alternatif sumber pendanaan (financing hierarchy) yang dapat dipilih oleh suatu perusahaan. Sumber pendanaan pertama perusahaan adalah dengan menggunakan spontaneous credit yang terdiri atas account payable dan accruals. Setelah itu, laba ditahan (retained earnings) dapat dijadikan sebagai sumber pendanaan berikutnya. Pemakaian kedua sumber dana ini dikarenakan keduanya tidak memiliki biaya atau beban yang harus dibayar oleh perusahaan. Setelah itu, jika pendanaan tersebut masih belum cukup, maka perusahaan baru menerbitkan hutang yang memiliki biaya modal yang masih tergolong kecil. Jika memang masih belum mencukupi juga, pilihan terakhir akan jatuh pada penerbitan saham baru.

Efisiensi operasional yang diukur menggunakan cost to revenue ratio berpengaruh negatif dan signifikan terhadap financial performance yang diukur dengan menggunakan return on equity (Ignat \& Feleaga, 2019). Rasio ini memberikan gambaran kepada investor tentang seberapa efisien perusahaan dapat berjalan, semakin rendah biayanya, berarti semakin besar keuntungan yang bisa didapat/diperoleh. Penelitian yang dilakukan oleh Almazari (2013) menunjukkan adanya pengaruh negatif antara efisiensi operasional yang diukur dengan cost to revenue ratio terhadap financial performance yang diukur dengan return on equity.

Efektivitas aset yang diukur menggunakan total assets turnover berpengaruh positif dan signifikan terhadap financial performance yang diukur dengan menggunakan return on equity (Nanavati, 2013). Rasio ini memberikan gambaran tentang efektivitas perusahaan menggunakan aset dalam menghasilkan penjualan, sehingga dapat meningkatkan pengembalian pemegang saham yang digunakan sebagai sumber pendanaan dari aset perusahaan. Penelitian yang dilakukan oleh Bhagyalakshmi \& Saraswathi (2019) menunjukkan adanya pengaruh positif antara efektivitas aset yang diukur menggunakan total assets turnover terhadap financial performance yang diukur dengan return on equity. 
Financial leverage yang diukur menggunakan debt to equity ratio digunakan untuk mengukur tingkat kemampuan perusahaan untuk melunasi hutang jangka panjangnya dengan menggunakan ekuitas (Atidhira \& Yustina, 2015). Semakin tinggi nilai DER berarti ROE suatu perusahaan juga tinggi, yang artinya DER memiliki pengaruh positif terhadap ROE (Moghadam \& Jafari, 2015). Hal ini bertentangan dengan pendapat Ahmad et. al., (2015) yang mengatakan bahwa perusahaan yang memiliki DER tinggi akan memiliki nilai ROE yang rendah dibandingkan dengan perusahaan yang memiliki DER rendah akan memiliki nilai ROE yang tinggi. Dikarenakan penggunaan hutang yang tinggi, akan menimbulkan biaya bunga sebagai pengurang dari keuntungan bagi pemegang saham. Menurunnya keuntungan tersebut menyebabkan nilai ROE sebagai tingkat pengembalian bagi pemegang saham akan ikut turun.

Hipotesis dalam penelitian ini berdasarkan Gambar 1. di atas adalah:

$\mathrm{H}_{1}$ : Efisiensi operasional (CRR) berpengaruh negatif dan signifikan terhadap financial performance (ROE).

$\mathrm{H}_{2}$ : Efektivitas aset (TATO) berpengaruh positif dan signifikan terhadap financial performance (ROE).

$\mathrm{H}_{3}$ : Financial leverage (DER) berpengaruh positif dan signifikan terhadap financial performance (ROE).

Kerangka pemikiran dalam penelitian ini ada pada Gambar 1. di bawah ini:

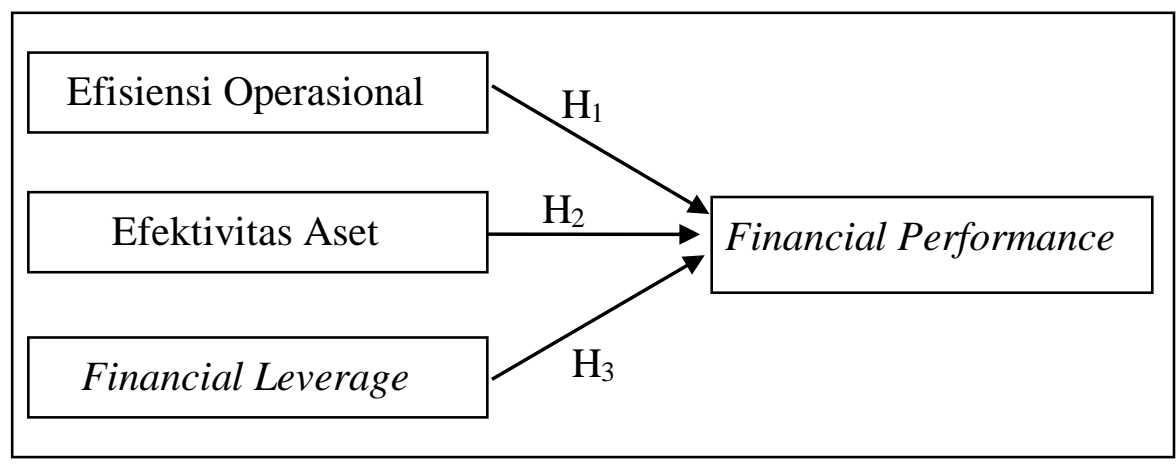

Gambar 1. Kerangka Pemikiran

\section{METODOLOGI}

Obyek Penelitian. Penelitian ini menggunakan perusahaan industri dasar dan kimia yang terdaftar di Bursa Efek Indonesia ada tahun 2014 sampai dengantahun 2018 yang memenuhi kriteria pemilihan sampel yang telah ditetapkan dalam penelitian. Kriteria pemilihan sampel yang digunakan dalam penelitian ini adalah: 1) Perusahaan industri dasar dan kimia yang terdaftar di Bursa Efek Indonesia secara berturut-turut pada tahun 2014 - 2018; 2) Perusahaan industri dasar dan kimia yang mempublikasi laporan keuangan secara lengkap pada periode $2014-2018$.

Penelitian ini yang bersumber dari situs www.idx.co.id, www.idnfinancials.com/id dan dari situs perusahaan yang bersangkutan untuk memperoleh laporan keuangan masingmasing perusahaan industri dasar dan kimia yan terdaftar di BEI selama tahun $2014-2018$. Penelitian ini menggunakan tiga variabel independen yaitu efisiensi operasional yang diukur dengan CRR, efektivitas aset yang diukur dengan TATO, dan financial leverage yang diukur dengan DER. Variabel dependen yang digunakan dalam penelitian ini adalah financial performance yang diukur dengan ROE.

Financial performance ini diukur dengan menggunakan return on equity. Perhitungan rumus sebagai berikut: 


$$
\mathrm{ROE}=\frac{\text { Net Income }}{\text { Total Equity }}
$$

Efisiensi operasional ini diukur dengan menggunakan cost to revenue ratio. Perhitungan rumus sebagai berikut:

$$
\mathrm{CRR}=\frac{\text { Total Cost }}{\text { Sales }}
$$

Efektivitas aset ini diukur dengan menggunakan rasio Total Aset Turnover. Perhitungan rumus sebagai berikut:

$$
\text { TATO }=\frac{\text { Sales }}{\text { Total Assets }}
$$

Financial leverage ini diukur dengan menggunakan rasio Debt to Equity Ratio. Perhitungan rumus sebagai berikut:

$$
\mathrm{DER}=\frac{\text { Total Debts }}{\text { Total Equity }}
$$

Penelitian ini menggunakan uji statistik deskriptif untuk mengetahui gambaran dari obyek penelitian. Uji Likelihood (Chow test), uji Hausman, dan uji Lagrange Multiplier untuk mengetahui estimasi model data panel yang sebaiknya digunakan dalam penelitian ini. Penelitian ini melakukan uji Multikolinearitas untuk mengetahui apakah terdapat hubungan antara seluruh variabel independen yang digunakan. Penelitian ini menggunakan uji koefisien determinasi berganda, uji secara simultan, dan uji secara parsial dalam melaukan uji hipotesis.

\section{HASIL UJI STATISTIK}

Uji Statistik Deskriptif. Hasil uji statistik deskriptif dalam penelitian ini menunjukkan bahwa variabel ROE memiliki nilai rata-rata (mean) sebesar 0.102932 dan nilai tengah (median) 0.061700 dengan standar deviasi sebesar 0.477648. Nilai maksimum sebesar 5.512000 dan nilai minimum sebesar -1.5773000; Variabel CRR memiliki nilai rata-rata (mean) sebesar 1.190437 dan nilai tengah (median) 0.967300 dengan standar deviasi sebesar 2.715866. Nilai maksimum sebesar 44.45100 dan nilai minimum sebesar 0.554100; Variabel TATO memiliki nilai rata-rata (mean) sebesar 1.117149 dan nilai tengah (median) 0.844600 dengan standar deviasi sebesar 1.192170. Nilai maksimum sebesar 8.429300 dan nilai minimum sebesar 0.00080; Variabel DER memiliki nilai rata-rata (mean) sebesar 1.577860 dan nilai tengah (median) 0.948600 dengan standar deviasi sebesar 3.347621. Nilai maksimum sebesar 39.48580 dan nilai minimum sebesar -6.930000.

Estimasi Model Data Panel. Hasil uji Likelihood (Chow test) yang dilakukan dalam penelitian ini menunjukkan bahwa nilai probability Cross-Section F: $0.0356<0.05$, sehingga penelitian ini sebaiknya menggunakan fixed effect model. Hasil uji Hausman yang dilakukan dalam penelitian ini menunjukkan bahwa nilai probability Cross-Section random: 0.2359 > 0.05 sehingga penelitian ini sebaiknya menggunakan random effect model. Penelitian ini tidak melakukan uji Lagrange Multiplier karena uji Likelihood (Chow test) dan uji Hausman yang dilakukan menunjukkan bahwa penelitian ini sebaiknya menggunakan random effect model. 
Tabel 1. Hasil Uji Chow

Test cross-section fixed effects

\begin{tabular}{lrrr}
\hline \hline Effects Test & Statistic & d.f. & Prob. \\
\hline \hline Cross-section F & 1.452218 & $(52,209)$ & 0.0356 \\
Cross-section Chi-square & 81.739998 & 52 & 0.0053 \\
\hline \hline
\end{tabular}

Tabel 2. Hasil Uji Hausman

\begin{tabular}{lrrrr} 
Test cross-section random effects & & & \\
\hline \hline Test Summary & Chi-Sq. Statistic & Chi-Sq. d.f. & Prob. \\
\hline \hline Cross-section random & 4.248369 & 3 & 0.2359 \\
\hline \hline
\end{tabular}

Uji Asumsi Klasik. Penelitian ini menggunakan uji korelasi antar variabel independen dalam menentukan apakah terdapat masalah multikolinearitas atau tidak. Penelitian ini tidak melakukan uji autokorelasi karena uji autokorelasi hanya dilakukan pada data yang diurutkan menurut waktu atau ruang (time-series) dan uji normalitas hanya perlu dilakukan jika jumlah observasi dalam suatu penelitian memiliki jumlah observasi kurang dari 30 observasi (Ajija dkk., 2011). Uji Multikolinearitas yang dilakukan dalam penelitian ini menunjukkan bahwa variabel independen yang digunakan dalam penelitian ini memiliki nilai koefisien korelasi < 0,8 sehingga tidak terjadi multikolinearitas antara setiap variabel yang digunakan dalam penelitian ini.

Tabel 3. Hasil Uji Multikolinearitas

\begin{tabular}{crrr} 
& \multicolumn{1}{c}{ CRR } & \multicolumn{1}{c}{ TATO } & DER \\
\hline \hline CRR & 1.000000 & -0.080269 & 0.048772 \\
TATO & -0.080269 & 1.000000 & 0.084560 \\
DER & 0.048772 & 0.084560 & 1.000000
\end{tabular}

Uji Analisis Berganda. Hasil penelitian yang dilakukan dengan menggunakan random effect model menghasilkan hasil pengujian analisis berganda tabel 4 di bawah ini:

Tabel 4. Hasil Uji Analisis Berganda

\begin{tabular}{crrrr}
\hline \hline Variable & Coefficient & Std. Error & t-Statistic & Prob. \\
\hline \hline C & -0.038793 & 0.043664 & -0.888432 & 0.3751 \\
CRR & -0.019622 & 0.009522 & -2.060675 & 0.0403 \\
TATO & 0.058058 & 0.024681 & 2.352300 & 0.0194 \\
DER & 0.063519 & 0.007902 & 8.038597 & 0.0000 \\
\hline \hline & Weighted Statistics & & \\
\hline \hline & & & & \\
R-squared & 0.226754 & & & \\
Adjusted R-squared & 0.217866 & & & \\
F-statistic & 25.51276 & & & \\
Prob(F-statistic) & 0.000000 & & & \\
\hline \hline
\end{tabular}


Persamaan regresi yang digunakan dalam penelitian ini mengacu pada hasil uji analisis regresi linear berganda di atas adalah:

$$
\mathrm{ROE}=-0.038793-0.019622 \mathrm{CRR}+0.058058 \mathrm{TATO}+0.063519 \mathrm{DER}+\varepsilon_{i t}
$$

Persamaan di atas menunjukkan bahwa ROE akan memiliki nilai sebesar negatif 0.038793. Hal ini menunjukkan bahwa ROE akan memiliki nilai sebesar -0.038793 ketika CRR, TATO, dan DER bernilai nol; peningkatan CRR sebesar satu satuan akan mengakibatkan penurunan pada nilai ROE sebesar 0,019622. Sebaliknya, nilai ROE akan mengalami peningkatan sebesar 0,019622 ketika nilai CRR mengalami penurunan sebesar satu satuan; peningkatan TATO sebesar satu satuan akan mengakibatkan kenaikan pada nilai ROE sebesar 0,058058. Sebaliknya, nilai ROE akan mengalami penurunan sebesar 0,058058 ketika nilai TATO mengalami penurunan sebesar satu satuan; peningkatan nilai DER sebesar satu satuan akan mengakibatkan nilai ROE mengalami peningkatan sebesar 0,063519. Sebaliknya, nilai ROE akan mengalami penurunan sebesar 0,063519 ketika nilai DER mengalami penurunan sebesar satu satuan.

Uji secara parsial (uji t) dilakukan dengan tujuan untuk mengetahui apakah variabel independen secara parsial mampu mempengaruhi variabel dependen. Nilai probability $<0,05$ menunjukkan bahwa $\mathrm{H}_{0}$ ditolak sehingga masing-masing variabel independen yaitu CRR, TATO, dan DER secara parsial mampu mempengaruhi ROE secara signifikan. Nilai probability $>0,05$ menunjukkan bahwa $\mathrm{H}_{0}$ tidak ditolak sehingga masing-masing variabel independen CRR, TATO, dan DER secara parsial tidak mampu mempengaruhi ROE secara signfikan. Tabel 4. merupakan hasil uji secara parsial (uji t) yang dilakukan dalam penelitian ini.

Tabel 4. menunjukkan bahwa CRR memiliki nilai probability sebesar 0,0403. Nilai probability $<0,05$ menunjukkan bahwa $\mathrm{H}_{0}$ ditolak sehingga CRR secara parsial mampu mempengaruhi ROE secara signifikan. Tabel 4. di atas menunjukkan TATO bersih memiliki nilai probability sebesar 0,0194 . Nilai probability $<0,05$ menunjukkan bahwa $\mathrm{H}_{0}$ ditolak sehingga TATO secara parsial mampu mempengaruhi ROE secara signifikan. Tabel 4. di atas menunjukkan bahwa DER memiliki nilai probability sebesar 0,0000. Nilai probability $<0,05$ menunjukkan bahwa $\mathrm{H}_{0}$ ditolak sehingga DER secara parsial mampu mempengaruhi $\mathrm{ROE}$ secara signifikan.

Uji secara simultan (uji F) dilakukan dengan tujuan untuk mengetahui apakah variabel independen secara simultan (bersama-sama) mampu mempengaruhi variabel dependen. Nilai probability $<0,05$ menunjukkan bahwa $\mathrm{H}_{0}$ ditolak sehingga semua variabel independen yaitu CRR, TATO, dan DER secara simultan mampu mempengaruhi ROE secara signifikan. Nilai probability $>0,05$ menunjukkan bahwa $\mathrm{H}_{0}$ tidak ditolak sehingga semua variabel independen CRR, TATO, dan DER secara simultan tidak mampu mempengaruhi ROE secara signfikan. Tabel 1. ini merupakan hasil uji secara simultan (uji F) yang dilakukan dalam penelitian ini.

Tabel 4. menunjukkan bahwa nilai probability F-statistic sebesar 0,0000. Nilai probability $<0,05$ menunjukkan bahwa $\mathrm{H}_{0}$ ditolak sehingga $\mathrm{CRR}$, TATO, dan DER secara simultan mampu mempengaruhi ROE secara signifikan.

Uji koefisien determinasi digunakan untuk mengukur atau menerangkan besarnya pengaruh variabel independen yakni CRR, TATO, dan DER terhadap variabel dependennya, ROE. Tabel 4. menunjukkan bahwa nilai nilai Adjusted $R$-squared sebesar 0.217866 atau $21.79 \%$. Hal ini berarti kontribusi masing-masing variabel independen dalam menjelaskan variabel dependen sebesar $21.79 \%$. Sedangkan sisanya, sebesar 0.782134 atau $78.21 \%$ dapat dijelaskan oleh faktor lain atau variabel lainnya yang tidak digunakan dalam penelitian ini. 


\section{DISKUSI}

Hasil uji secara parsial (uji t) menunjukkan CRR, TATO, dan DER secara parsial mampu mempengaruhi ROE secara signifikan. Nilai ROE akan ikut meningkat seiring dengan meningkatnya nilai TATO dan DER; sedangkan nilai ROE akan mengalami peningkatan ketika nilai CRR mengalami penurunan. Hasil uji secara simultan (uji F) menunjukkan CRR, TATO, dan DER secara simultan (bersama-sama) mampu mempengaruhi ROE secara signifikan.

\section{KESIMPULAN DAN SARAN}

Hasil dalam penelitian ini menunjukkan bahwa factor yang dapat mempengaruhi financial performance perusahaan industri dasar dan kimia yang terdaftar di bursa efek pada tahun 2014 sampai dengan tahun 2018 yaitu efisiensi operasional, efektivitas asset, dan financial leverage. Efisiensi operasional yang diukur dengan CRR memiliki pengaruh yang negative signifikan terhadap financial performance yang diukur dengan ROE. Sedangkan efektivitas asset yang diukur dengan TATO dan financial leverage yang diukur dengan DER memiliki pengaruh positif signifikan terhadap financial performance yang diukur dengan ROE.

Keterbatasan yang terdapat dalam penelitian ini adalah variabel independen yang digunakan untuk menjelaskan financial performance hanya berjumlah tiga variabel dan penelitian ini hanya menggunakan perusahaan industry dasar dan kimia sebagai sampel untuk mengetahui pengaruh efisiensi operasional,efektivitas asset, dan financial leverage terhadap financial performance. Selain itu, penelitian ini hanya menggunakan lima tahun penelitian dimulai dari tahun 2014 sampai dengan tahun 2018.

Keterbatasan yang terdapat dalam penelitian ini menimbulkan beberapa saran untuk penelitian selanjutnya. penelitian selanjutnya dapat menggunakan lebih banyak variabel bebas seperti menggunakan 5 ways DuPont Analysis, ukuran perusahaan, serta working capital. Penambahan variabel independen dalam penelitian tersebut diharapkan dapat membantu manajer untuk melihat informasi keuangan perusahaan yang memiliki dampak bagi financial performance di masa yang akan datang.

\section{DAFTAR RUJUKAN/PUSTAKA}

Almazari, A. A. (2013). Capital Adequacy, Cost to Revenue Ratio and the Performance of Saudi Banks. International Journal of Academic Research in Accounting, Finance and Management Sciences .

Atidhira, A. T., \& Yustina, A. I. (2015). The Influence of Return on Asset, Debt to Equity Ratio, Earnings per Share, and Company Size on Return in Property and Real Estate Companies. Journal of Applied Accounting and Finance .

Batchimeg, B. (2017). Financial Performance Determinants of Organizations: The Case of Mongolian Companies. Journal of Competitiveness , 22 - 33.

Bhagyalakshmi, K., \& Saraswathi, S. (2019). A Study On Financial Performance Evaluation Using DupontAnalysis in Select Automobile Companies. International Journal of Management .

Brigham, E. F., \& Houston, J. F. (2015). Fundamentals of Financial Management. Cengage. Gitman, L. J., \& Zutter, C. J. (2015). Managerial Finance. pearson.

Ignat, I., \& Feleaga, L. (2019). The Role of it in the logistics sector: the impact of dupont model on the profitability of it companies.

Nanavati, N. K. (2013). Dupont Analysis to Measure Return On Equity Of Satyam Computer Services Limited. 
Warrad, L. H., \& Nassar, M. (2017). Could Profitability, Activity and Use of Equity Finance Increasing DuPont Model of Return on Equity. International Review Management and Marketing .

Situs (Website) Resmi Bursa Efek Indonesia : https://www.idx.co.id

Situs (Website) Saham OK : https://www.sahamok.com 